\title{
The REDD+ Governance Landscape and the Challenge of Coordination in Brazil
}

\author{
Leandra Fatorelli, Maria Fernanda Gebara, Peter May, Shaozeng Zhang and Monica Di Gregorio
}

\section{Key points}

- Despite significant efforts towards the coordination of governance related to REDD+ (Reducing Emissions from Deforestation and Forest Degradation), it remains a major challenge in Brazil. This challenge is pervasive whether between government levels (as evidenced in the differences in REDD+ perspectives and interests between federal and state governments), civil society or between government and the private sector.

- Despite their clear mandate to do so, state actors exchange only limited information on REDD+ policy with non-state actors.

- Domestic NGOs play an important mediating role in the limited REDD+ coordination that does take place.

- $\quad$ Private-sector actors, one of the main forces driving deforestation and forest degradation, are largely absent from the REDD+ policy domain, and the few who do participate are relatively isolated from other REDD+ policy actors.

\section{Introduction}

REDD+ has the objective to reduce greenhouse gas emissions from deforestation and forest degradation and to increase the removal of greenhouse gases through enhancement of forest carbon stocks (Angelsen et al. 2009; Angelsen et al. 2012). Brazil has long been a key actor in global climate change negotiations, making commitments to avoid deforestation and forest degradation and undertaking important steps to accomplish REDD+ objectives (May et al. 2011).

As in other countries, achieving REDD+ goals in Brazil depends not just on the forestry sector but on all of the sectors that drive deforestation and forest degradation, including agriculture, animal husbandry and infrastructure development. This requires well-integrated cross-sectoral policies, since no single sector or actor can properly address problems such as deforestation, that span ecological, social, political, administrative and legal boundaries (Shannon 2003). REDD+ governance in Brazil is characterized by the interaction of a variety of state and nonstate actors in policy-making networks (May et al. 2011), and is no longer a centralized and top-down process (Börzel 1997; Börzel and Heard-Lauréote 2009). Yet policies still tend to be disconnected from one another, even though they are nested under potentially connected policy arenas (Gebara et al. 2014).

In recent years, important steps have been taken in Brazil to establish multi-actor councils and institutional spaces for planning. Policy dialogue now occurs regularly between different branches of government and relevant stakeholders on forestry issues related to the Amazon region. At the federal level, such spaces include the Coordinating Commission for the National Forestry Program, the National Environmental Council and the Inter-ministerial Working Group on the Action Plan for Prevention and Control of Deforestation in the Legal Amazon.

Key coordinating bodies involved in developing a national REDD+ strategy are the Permanent Inter-ministerial Working Group for Reducing Legal Amazon Deforestation Rates (GPTI) and the Inter-ministerial Committee on Climate Change (CIM). CIM has no meetings in 2014; and the Gex (the CIM executive group) met only twice on 2014 (Ministry of Environment 2014a). At the time this brief was published, GPTI had not met since 2008.

Failures to deliver intended policy outcomes can be seen as a systemic problem, not restricted to policy instruments, but rather associated with their administrative systems (Walker 2004). Creating new bodies to address REDD+ or other climate change issues will help achieve climate change objectives only if there is sustained coordination and collaboration to that end. To achieve significant outcomes, such efforts require resources including as money, time, and human and political capital. Further, repeated government action in creating, merging or dismantling bodies and departments might contribute to fragmentation more than to integration (Walker 2004). 
The draft of the National Strategy for REDD+ (Government of Brazil 2013) describes clear coordination and governance objectives, such as integration, convergence and coordination among instruments (public policies) and governance structures (i.e. national, state and local level) to reduce deforestation. According to the preliminary document, the national strategy will achieve these objectives through the prioritization of actions and articulation among government, civil society and private sectors. Yet how these objectives will be achieved remains underspecified.

This brief reviews the major coordination challenges of REDD+ and related policies in Brazil, based on a questionnaire and in-depth interviews with 56 institutional representatives from different organizations - government, NGOs and civil society organizations, research institutions, private-sector organizations and donors - conducted in 2010 and 2011 as part of CIFOR's ongoing research on REDD+ policy processes. It identifies governance constraints that inhibit effective coordination and implementation of REDD+ policies.

\section{Coordinating REDD+ implementation in Brazil}

In Decree no. 7390 Government of Brazil 2010, which regulates the National Policy for Climate Change (Government of Brazil 2009), Brazil developed a suite of sector-specific greenhouse gas mitigation actions designed to reduce greenhouse gas emissions by 36.1 to 38.9 percent (below a projected 2020 baseline). Previously Brazil had developed plans to combat deforestation in the Amazon and Cerrado biomes, and the national plan to control deforestation in the Amazon, initiated in 2004, was revised for 2012-2015 to scale up these actions (MMA 2013). According to the draft of the National REDD+ Strategy, sectoral plans must be integrated with existing measures for forest conservation and increased carbon storage. These existing measures could include, for example, state-level plans to reduce deforestation and the Amazon Fund (Government of Brazil 2013).

Improving policy coordination and harmonization of land-use policies is essential in order to effectively mitigate greenhouse gas emissions (Gebara and Thuault 2013). Successful coordination of policies requires (1) assessments and defined indicators for measuring the impacts and effectiveness of policies, so that it is possible to identify and change unsuccessful strategies; (2) new policy processes and procedures that facilitate dialogue and decision-making across different sectors (horizontal coordination) and governance levels (vertical coordination) on technical, political and institutional aspects of REDD+; (3) alignment between the sectoral plans and climate policies and those implemented across federal, state and municipal levels of government; (4) participation of civil-society, government and private-sector actors in policy dialogue and decision making; and (5) mainstreaming low-carbon and climate-resilient development into major Brazilian sectoral economic policy measures (Gebara and Thuault 2013).

One of the three multi-stakeholder working groups that operated during 2010 to provide input to the national REDD+ strategy specifically addressed coordination, institutional arrangements and participation. It identified three elements as fundamental for the development of an integrated national REDD+ strategy:
(1) distribution of rights and responsibilities, (2) overcoming the transaction costs of policy integration and coordination and (3) analysis of how institutional structures influence the perspectives of actors, interests and motivations (Ministry of Environment 2011). The working group also recognized that while many actions to reduce deforestation are best applied at state and municipal levels, such actions must be integrated into a national-level strategy to achieve long-term impact.

The draft national REDD+ strategy invokes the need to integrate REDD+ actions with a suite of policies and measures - the Action Plan for Prevention and Control of Deforestation in Amazon and Cerrado, the revised national forest legislation of 2012, the National Plan on Climate Change, and others. This illustrates the complexity and challenges for effective REDD+ policy implementation, but also the fact that government institutions recognize the need for policy integration.

Integrating REDD+ with other policies to avoid fragmentation of policies addressing climate change and deforestation is to be led by the REDD+ National Entity, through institutional arrangements between CIM (and its executive group - Gex) and GPTI.

The REDD+ National Entity would be responsible for promoting this integration by developing policies on carbon impact, and for seeking further synergies to maximize the effectiveness of those policies. However, the draft REDD+ strategy does not yet detail the specific actions and mechanisms that would be needed to achieve the expected coordination among government actors and between government, civil society and the private sector.

The REDD+ agenda reiterates persistent issues already on the policy agenda in Brazil, such as deforestation, lack of, and contested, land rights, inequality, and also brings to the forefront new issues such as the distribution of REDD+ benefits, technical capacity for implementation, and access to REDD+ related information. Thus, the draft strategy recognizes the complementarity of REDD+ with distinct policies within and outside the forestry sector. Debate continues about how to best achieve policy integration across different sectors and administrative levels.

\section{Coordination challenges}

The Working Group on REDD+, under CIM's executive group, designed the draft of the REDD+ strategy between 2011 and 2013. The document was updated twice: once in December 2013 and once following the Warsaw Framework on REDD+ (produced by the 19th session of the Conference of the Parties to the United Nations Framework Convention on Climate Change in November 2013). CIM's executive group completed the revisions in May 2014, and the document is due for CIM approval (Ministry of Environment 2014b). At the time this brief was published, the REDD+ strategy document was not yet released. A final public consultation is foreseen, and the period of consultation and review will be defined by CIM (Ministry of Environment 2014b). Overall finalization of the strategy document is taking longer than expected, and it is associated with other REDD+ efforts. In parallel with the strategy process, Brazil conducted the forest reference levels (FREL) and submitted the document to the UNFCCC in June 2014 to pass through the evaluation process. Only after the evaluation of the Annex REDD+ of the Biennial Update Reporting the reducing emissions results from deforestation control will be 
considered measured, reported and verified, enabling the country to receive the payments for REDD+ (Ministry of Environment 2014c). Domestically, Brazil is trying to finalize the Environmental Rural Registry (CAR) to regulate all rural properties. By January $2015,11 \%$ of properties were registered under CAR (Government of Brazil 2015). The readiness process, not only the REDD+ strategy elaboration itself, has proved challenging.

Participants in this study agreed that the following were significant issues (percentages refer to how many interviewees chose each statement as an important challenge):

- $\quad$ the need for more effective coordination between civil society, government and the private sector (86\%)

- contradictions between forestry policies and other policies (80\%)

- lack of law enforcement (77\%)

- lack of information on land tenure (75\%)

- $\quad$ the need to tackle deforestation without compromising development goals (75\%)

- $\quad$ stakeholders' lack of knowledge on REDD+ (75\%)

- the need to reach consensus on forest management and land use plans (73\%)

These findings suggest that effective coordination is the major challenge for the national REDD+ strategy and that REDD+ governance in Brazil is still fragile. This can constrain effective REDD+ policy making. In other words, insufficient operational structures are in place to effectively facilitate coordination between policy actors in order to achieve synergies among their distinct capacities and competencies. These structural dimensions should be dealt with in the design of the national strategy. The thinking of government actors is evolving towards giving multiactor organizations more responsibilities and decision-making power to lead a coordination process, while implementation is proceeding at a slow pace (Shannon 2003).

Contradictions between forestry policy and other policies were perceived by $80 \%$ of our interviewees as a major challenge, including for government actors. Despite significant progress in some areas, mainstreaming forest conservation in development policies for the Brazilian Amazon still tends to be characterized by top-down decision making, institutional fragmentation, lack of horizontal coordination (sectoral politics) and vertical coordination (inter-state differences) and tension between developmental and environmental goals, particularly in the agribusiness, electrical energy and transportation sectors (May et al. 2011).

Effectively addressing the main drivers of deforestation without compromising development objectives was indicated as a major challenge by three-quarters of the respondents. There is a clear relationship between economic growth, the drivers of deforestation and climate change impacts. In the National Plan on Climate Change, this relationship is translated into actions and targets to mitigate emissions. The targets are defined by sector and are imbalanced when comparing mitigation opportunities (which primarily target changes in the land use, forestry, agriculture and livestock sectors) with investment plans (which primarily target the energy and infrastructure sectors). Not enough resources go to those sectors or parties where most emission reductions could be achieved (Cenamo 2014; GCF 2014). Amazonian state governments have agreed among themselves on aspects of the REDD+ governance structure (e.g. they asked for decentralization and autonomy of states in implementation and monitoring of REDD+), and on benefit sharing and mechanisms to foster REDD+ in Brazil. These proposals diverge from the draft Federal REDD+ strategy (GCF 2014).

Other factors - such as delay in the clarification of tenure rights, lack of consensus on forest management and land use plans, and lack of capacity to enforce the laws and regulations -are also recognized as hampering the possible effectiveness of the REDD+ national strategy. Government actors leading the REDD+ process should promote incentives to encourage sustainable land use and the clarification of tenure rights (directly related to benefit sharing strategies and the definition of carbon rights) before implementing the national strategy. More effective law enforcement institutions and procedures would help to overcome the constraints on addressing illegal deforestation. Other challenges pointed out by study participants included the lack of formal institutions for REDD+ and insufficient law enforcement, the need for a nested approach for REDD+ initiatives to be able to make reductions accountable at the national level, and the need to define the beneficiaries of REDD+ compensation.

\section{Who facilitates information exchange and collaboration?}

The government of Brazil identified the Amazon biome as the strategic target to control deforestation because of its significant role in global deforestation rates (May et al 2011). While Brazil has established inter-ministerial groups to lead cross-sectoral dialogue and action on climate change, including REDD+ efforts, these arrangements might not be sufficient or effective. The investigation of policy actors interplay reveal governance structural aspects for coordination, consensus building, participation and cohesion (Bodin and Prell 2011; Sandström 2011). Investigating how policy actors in the national REDD+ policy arena interact in Brazil can shed light on barriers and opportunities for governance. This study sought to understand the REDD+ arena's networks of information exchange and collaboration. Focusing on policy actors associated with the Amazon biome.

Networking patterns were elicited through a questionnaire, asking participants to indicate which other organizations in the REDD+ domain they exchanged information and collaborated with. UCINET software was used to calculate network measures, and visualization of networks was undertaken with NETDRAW (Borgatti 2002; Borgatti et al. 2002). The analysis considered only reciprocal ties, in which each actor recognized the other as an information or collaboration partner. Such ties are likely to indicate stronger links than one-directional ties.

Both networks (information exchange and collaboration) present a good level of cohesion (most actors are linked directly to each other or indirectly through other actors), with fewer isolated actors in the information exchange network than in the collaboration network. We identified actors who play a central role in the REDD+ networks, based on how many reciprocal ties they have with other actors, and actors who play a mediating role, based on how often they connect different types of actors in the network. In both networks, the actors with the most 
central and mediating roles are predominantly domestic NGOs. But other types of actors also play central and mediating roles, especially in the information network. NGOs in particular are linked both to other NGOs and to other actors (state officials, international actors and research institute staff). State actors, in contrast, are connected primarily to different types of actors but indicate limited reciprocal information ties among themselves. This might indicate that the inter-ministerial committee, for example, is not as effective as it should be in facilitating information exchange.

The collaboration network is smaller than the information network, but even though smaller, it contains representatives from a range of sectors. NGOs form a cohesive group and are, in some cases, the only actors that other actors link to in the network. State actors are largely isolated, and those that are linked in the network tend to collaborate only with a limited number of other actors (state or otherwise).

Private-sector actors have a very limited presence in both networks and are completely isolated in the collaboration network. However, the four private-sector actors that are present are important businesses whose operations are directly related to land use issues or sustainable development. Only two privatesector actors engage in sustained and reciprocal information sharing: the Agriculture and Livestock National Confederation and the Brazilian Association of Vegetable Oil Industries. The Agriculture and Livestock National Confederation displays a reciprocal connection only to the National Environmental Council, a multi-actor, multi-sector consultative and deliberative board.

The private sector's lack of involvement in REDD+ initiatives has also been noted by those Amazon states that have been developing economic instruments to foster private-sector participation (Idesam 2012). This limited engagement might reflect uncertainties and controversies both within the sector and with other actors, for example about who should benefit from REDD+, whether REDD+ should or not be market-based, and the level of participation in REDD+ decision making (Bushley and Khatri 2011). The segregation of the private sector from reciprocal collaborative interactions in the REDD+ arena may undermine collaborative learning (Shannon 2003).

A number of organizations stand out as central actors and/or mediators in the information and collaboration networks. In both networks, half of these are NGOs. Most NGOs are also directly or indirectly connected to each other. This finding underlines the importance of domestic NGOs in facilitating information flows and collaboration. It is similar to Shannon's (2003) finding that NGOs are improving policy coordination and taking a leadership role in organizing policy communities. NGOs' relatively flexible organizational structure seems to facilitate this role. Among donors, the German Federal Enterprise for International Cooperation has a key role in facilitating information flows and a more limited but relevant role in collaboration.

In the government sector, the chief of staff of the presidency (Casa Civil), which leads the political process on climate change and deforestation, displays reciprocal ties only with the Ministry of Foreign Relations, and both remain disconnected from the main collaboration network. In the information network, the Ministry of Environment and two Amazon region state environmental secretariats (Amazonas and Acre) are the most well-connected government actors. However, they do not share links with the federal government actors in the collaboration network. In the information network only one secretariat has a link with a single federal government actor. The state governments of Acre and Amazonas have been establishing subnational policies on the control of deforestation, forest conservation, climate change and ecosystem services.

The Amazon states (two of which formed part of our study, i.e. Amazonas and Acre) submitted the document "Contributions by the States of the Legal Amazon to the National REDD+ Strategy" to the federal government in 2012. In 2014, the Governors' Climate and Forest Task Force published the document "Contributions to the National REDD+ Strategy: A Proposal for Allocation between States and the Union". The two documents sought to influence aspects of the REDD+ strategy such as the decentralization of regulation and the management of REDD+ resources, and their distribution between the federal government and the Amazon states, and to broaden participation in consultative, deliberative and executive bodies (GCF 2014). The latter document was a clear manifestation of disagreement by the states with what was being proposed in the draft National REDD+ Strategy and reflects the lack of strong collaborative relations between Amazon states and the federal government in the REDD+ arena (Figure 1). The Ministry of Environment is the most well-connected ministry in the collaboration network, showing that its formal coordination role is reflected in action. It is one of the main brokers among government actors. The Amazonas and Acre secretariats also facilitate exchanges between different types of actors. Yet a number of ministries and government institutions that are part of inter-ministerial bodies with climate-change and REDD+ related responsibilities remain disconnected from the collaboration network.

Figure 1 presents the findings from this network analysis. Annex 1 lists the actors represented in the analysis.

\section{Final remarks}

Brazilian federal institutions responsible for REDD+ policy development have established an approach to mainstreaming REDD+ into policies related to deforestation, forest conservation and restoration and low-carbon agricultural development, mechanisms to clarify tenure, improve enforcement and respect indigenous rights and broader development plans (MMA 2013). Yet major challenges remain in terms of effectively coordinating these efforts.

Network analysis reveals that leadership in information exchange and collaboration is exercised by both federal- and state-level government institutions - the Ministry of Environment, which is also the federal lead institution of three multi-actor bodies responsible for developing the national REDD+ strategy, the executive coordinator of the national plan to control deforestation in the Amazon, and the Amazon Fund. Yet the role of statelevel actors (such as the Sustainable Development Agency of Amazonas state and the Environmental Agency of Acre state) in national-level policy processes is prominent and indicates the strong interest they have and progress they have made towards the implementation of REDD+. The lack of connections between state and federal actors might reflect differences in interests about the REDD+ strategy, as declared by states in 2014. Ministries that make up the inter-ministerial bodies working on climate change 


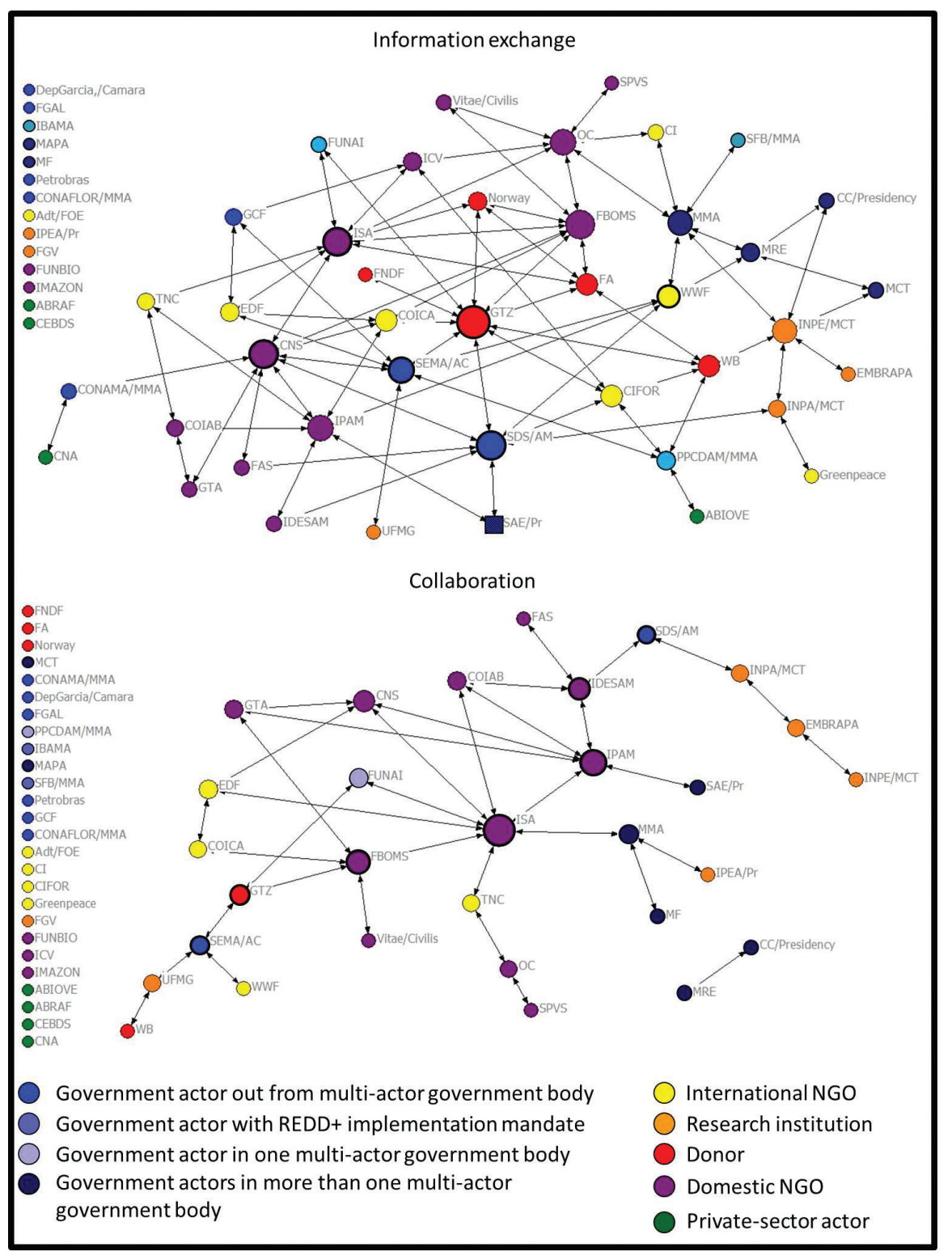

Figure 1. REDD+ governance networks in Brazil. Each circle represents an actor. The size of the circle represents the actor's centrality in the network, and the thickness of its border represents the extent to which that actor plays a mediating role. Lines represent reciprocal links; the circles on the left represent isolated actors.

are poorly connected - a sectoral compartmentalization that institutional efforts have so far not been able to overcome. With so many ministries on the periphery of the debates and integration efforts, it is difficult to envision how policy decisions or implementation can occur in a truly integrated fashion.

Domestic NGOs form the largest coalition in the collaboration network. This presence is important to support new directions for REDD+ in Brazil, but more efforts are needed to link with other types of actors. Private-sector actors are isolated despite their key role in driving deforestation and forest degradation.

To deal with complex cross-sectoral issues such as REDD+, intersectoral participation of policy-making actors is essential. This could be achieved, for example, through different spaces that stimulate dialogue concerning the integration and harmonization of sectoral policies (Bengston et al. 2004). Sectoral politics and inter-state differences in Brazil create contention regarding the technical designs of the REDD+ strategy, which actors attempt to influence to their own advantage. A more in-depth analysis of participatory processes to formulate the national REDD+ strategy was outside of the scope of this study, but could reveal in more detail the procedural and implementational bottlenecks in information and collaboration flows. Further research should also consider a longitudinal network study to explore how information and collaboration networks have evolved over time.

While our findings show that a lack of effective coordination is one of the major governance hurdles to achieving effective policy implementation of REDD+, they reflect a policy process in early evolution that is establishing new institutions and new relationships among actors from distinct sectors. 
These institutions and relationships are shaping new roles for policy actors to address deforestation and forest degradation. The challenge ahead relates to government and civil society successfully using their experience to work together to foster effective coordination and governance of multi-actor processes that effectively engage the private sector in REDD+.

\section{Acknowledgements}

The data and analysis presented in this brief are part of the policy component of the Global Comparative Study on REDD+ (http:// www.cifor.org/gcs), conducted by the Center for International Forestry Research. The policy research is led by Maria Brockhaus. The research methods were based on the Protocol for Policy Network Analysis, adapted by Monica Di Gregorio and Maria Brockhaus from methods developed by the Comparing Climate Change Policy Networks project, led by Jeffrey Broadbent (http://compon.org). We gratefully acknowledge the financial support received from the Norwegian Agency for Development Cooperation, the Australian Agency for International Development, the United Kingdom's Department for International Development, and the European Commission.

We want to express our sincere gratitude to two anonymous reviewers for very useful comments and to those who played highly valuable roles in research and writing support and editing, especially Maria Brockhaus and Rachel Carmenta.

\section{References}

Angelsen A, Brockhaus M, Kanninen M, Sills E, Sunderlin WD and Wertz-Kanounnikoff S, eds. 2009. Realising REDD+: National Strategy and Policy Options. Bogor, Indonesia: Center for International Forestry Research. http://www.cifor.org/ library/2871/realising-redd-national-strategy-and-policyoptions/

Angelsen A, Brockhaus M, Sunderlin WD and Verchot LV, eds. 2012. Analysing REDD+: Challenges and Choices. Bogor, Indonesia: Center for International Forestry Research. http:// www.cifor.org/library/3805/analysing-redd-challenges-andchoices/

Bengston DN, Fletcher JO and Nelson KC. 2004. Public policies for managing urban growth and protecting open space: Policy instruments and lessons learned in the United States. Landscape and Urban Planning 69:271-286.

Bodin Ö and Prell C. 2011. Social network analysis in natural resource governance - summary and outlook. In Bodin Ö and Prell C, eds. 2011. Social Networks and Natural Resource Management: Uncovering the Social Fabric of Environmental Governance. Cambridge: Cambridge University Press.

Borgatti SP. 2002. NetDraw Software for Network Visualization. Lexington, KY: Analytic Technologies.

Borgatti SP, Everett MG and Freeman LC. 2002. Ucinet for Windows: Software for Social Network Analysis. Harvard, MA: Analytic Technologies.

Börzel TA. 1997. What's so special about policy networks? An exploration of the concept and its usefulness in studying European governance. European Integration Online Papers 1(16). http://eiop.or.at/eiop/texte/1997-016a.htm
Börzel TA and Heard-Lauréote K. 2009. Networks in EU multi-level governance: Concepts and contributions. Journal of Public Policy 29(2):135-151. doi: 10.1017/S0143814X09001044

Bushley BR and Khatri DB. 2011. REDD+: Reversing, Reinforcing or Reconfiguring Decentralized Forest Governance in Nepal. Discussion Paper Series 11:3. Nepal: ForestAction.

Cenamo M. 2014. Até quando a Amazônia consegue pagar a conta do clima? Blog do Planeta, Revista Época. Accessed 18 October 2014. http://epoca.globo.com/colunas-e-blogs/ blog-do-planeta/noticia/2014/09/ate-quando-bamazoniabconsegue-pagar-conta-do-clima.html

[GCF] Governors' Climate and Forests Task Force. 2014. Contributions to the National REDD+ Strategy: A Proposal for Allocation between States and the Union. Manaus: Idesam and Governors' Climate and Forests Task Force.

Gebara M, Fatorelli L, May P and Zhang S. 2014. REDD+ policy networks in Brazil: Constraints and opportunities for successful policy making. Ecology and Society 19(3):53. doi: 10.5751/ ES-06744-190353

Gebara MF and Thuault A. 2013. GHG Mitigation in Brazil's Land Use Sector: An Introduction to the Current National Policy Landscape. Working Paper. Washington, DC: World Resources Institute. http://wri.org/publication/ghg-mitigationbrazil-land-use-sector

Government of Brazil. 2013. Estratégia nacional de REDD+ do Brasil. Versão preliminar. Brasília, DF, Brazil: Comitê Interministerial de Mudança do Clima, Grupo Executivo sobre Mudanças Climáticas and Grupo de Trabalho Interministerial sobre REDD+.

Government of Brazil. 2009. Lei no 12.187, de 29 de dezembro de 2009. Institui a Política Nacional sobre Mudança do Clima PNMC e dá outras providências. Brasília, Brazil: Casa Civil, Presidência da República.

Government of Brazil. 2010. Decreto no 7.390 de dezembro de 2010. Regulamenta os arts. 60, 11 e 12 da Lei no 12.187, de 29 de dezembro de 2009, que institui a Política Nacional sobre Mudança do Clima - PNMC, e dá outras providências. Brasília, Brazil: Casa Civil, Presidência da República.

Government of Brazil. 2015. Cadastro Ambiental Rural já tem 576 mil imóveis registrados. Accessed 1 February 2014. http:// www.brasil.gov.br/economia-e-emprego/2015/01/cadastroambiental-rural-ja-tem-576-mil-imoveis-registradosMay PH, Millikan B and Gebara MF. 2011. The Context of REDD+ in Brazil: Drivers, Agents and Institutions. Occasional Paper 55, 2nd ed. Bogor, Indonesia: Center for International Forestry Research.

[MMA] Ministério de Meio Ambiente. 2011. REDD+: Documentosíntese com subsídios de múltiplos atores para a preparação de uma Estratégia Nacional. Brasília, Brazil: MMA.

[MMA] Ministério do Meio Ambiente. 2013. Plano de Ação para prevenção e controle do desmatamento na Amazônia Legal (PPCDAm): 3a fase (2012-2015) pelo uso sustentável e conservação da Floresta / Ministério do Meio Ambiente e Grupo Permanente de Trabalho Interministerial. Brasília, Brazil: MMA.

[MMA] Ministério do Meio Ambiente. 2014a. Reuniões do Grupo Executivo sobre Mudança do Clima - Gex. Webpage presenting the meetings attendance lists and minutes. Accessed 20 December 2014. http://www.mma.gov.br/clima/ grupo-executivo-sobre-mudanca-do-clima/grupo-executivosobre-mudanças-climáticas/item/326

[MMA] Ministério do Meio Ambiente. 2014b Dúvida encaminhada ao Sistema de Acesso à Informação - SIC/MMA n 641 - sobre consulta pública da Estratégia Nacional de REDD+. 
[MMA] Ministério do Meio Ambiente. 2014c. O nível de referência de emissões florestais do brasil para pagamentos por resultados de redução de emissões provenientes do desmatamento no bioma amazônia. Notes on REDD+ in the MMA website. Accessed 1 February 2015. http://www.mma. gov.br/redd/images/Publicacoes/nota_FREL_26nov2014.pdf Sandström A. 2011. Social networks, joint image building, and adaptability: The case of local fishery management. In Bodin Ö and Prell C, eds., Social Networks and Natural Resource
Management: Uncovering the Social Fabric of Environmental Governance. Cambridge: Cambridge University Press . 288-321. Shannon MA. 2003. Mechanisms for coordination. In Dubé YC and Schmithüsen F, eds. Cross-Sectoral Policy Impacts between Forestry and Other Sectors. Forestry Paper 142. Rome: Food and Agriculture Organization. 145-159.

Walker A. 2004. Understanding social capital within community/ government policy networks. Social Policy Journal of New Zealand 22:1-18.

\section{Annex 1. Network actors}

\begin{tabular}{|c|c|}
\hline Abbreviation & Name \\
\hline ABAG & Brazilian Association of Agribusiness \\
\hline ABEMC & Brazilian Association of Carbon Market Enterprises \\
\hline ABIOVE & Brazilian Association of Vegetal Oil Industries \\
\hline ABRAF & Brazilian Association of Planted Forest Producers \\
\hline AdT & Friends of the Earth, Brazilian Amazon \\
\hline CC/Pr. & Executive Office (Casa Civil) of the Presidency of the Republic \\
\hline CEBDS & Brazilian Business Council for Sustainable Development \\
\hline Cl-Brasil & Conservation International \\
\hline CIFOR & Center for International Forestry Research \\
\hline CLUA & Climate and Land Use Alliance \\
\hline CNA & National Confederation of Agriculture and Livestock \\
\hline CNS & National Council of Rubber Tappers \\
\hline COIAB & Coordination of Indigenous Organizations of the Brazilian Amazon \\
\hline COICA & Coordination of Indigenous Organizations of the Amazon Basin \\
\hline CONAFLOR & National Commission on Forests \\
\hline CONAMA & National Environmental Council \\
\hline Dep. Garcia/Câmara & National Chamber of Deputies \\
\hline EDF-EUA & Environmental Defense Fund \\
\hline EMBRAPA & Brazilian Enterprise for Agricultural and Livestock Research \\
\hline FA/BNDES & Amazon Fund \\
\hline FAS & Sustainable Amazonas Foundation \\
\hline FBMC & Brazilian Forum on Climate Change \\
\hline FBOMS & Brazilian Forum of Social Movements and NGOs \\
\hline FGAL & Forum of Governors of the Legal Amazon Region \\
\hline FGV/Ces & Getúlio Vargas Foundation \\
\hline FIESP & Federation of Industries of the State of São Paulo \\
\hline FNDF & National Fund for Forest Development \\
\hline FUNAI & National Indian Foundation \\
\hline FUNBIO & Brazilian National Biodiversity Fund \\
\hline GCF & Governors' Climate and Forests Task Force \\
\hline GEF & Global Environmental Facility \\
\hline Greenpeace & Greenpeace \\
\hline GTA & Amazonian Working Group \\
\hline GTZ & German Federal Enterprise for International Cooperation \\
\hline IBAMA & Brazilian Institute of Environmental Protection and Renewable Natural Resources \\
\hline
\end{tabular}


Annex 1. Continue

\begin{tabular}{ll}
\hline Abbreviation & Name \\
\hline ICV & Institute Center of Life \\
\hline IDESAM & Institute of Conservation and Sustainable Development of Amazonas \\
\hline IMAFLORA & Institute for Agricultural and Forest Management and Certification \\
\hline IMAZON & Amazon Institute of People and the Environment \\
\hline INPA & National Institute of Amazon Research \\
\hline INPE & National Institute of Space Research \\
\hline IPAM & Institute of Environmental Research of the Amazon \\
\hline IPEA & Institute of Applied Economic Research \\
\hline ISA & Socio-Environmental Institute \\
\hline MAPA & Ministry of Agriculture, Livestock and Food Supply \\
\hline MCTI & Ministry of Science, Technology and Innovation, \\
\hline MMA & Ministry of Environment, \\
\hline MRE & Ministry of Foreign Relations, \\
\hline Norway & Norwegian Embassy in Brazil \\
\hline OC & Climate Observatory \\
\hline Petrobras & Brazilian Petroleum Corporation \\
\hline PPCDAM & Inter-ministerial Working Group for the Action Plan for the Prevention and Control of Deforestation in the \\
\hline SAE/Pr. & Legal Amazon \\
\hline SDS-AM & Secretariat of Strategic Affairs of the Presidency of the Republic \\
\hline SEMA-AC & State Secretariat of Environment and Sustainable Development, Amazonas \\
\hline SFB & State Secretariat of Environment, Acre \\
\hline SPE/MF & Brazilian Forestry Service \\
\hline SPVS & Ministry of Treasury \\
\hline TNC-Brasil & Society of Wildlife Research and Environmental Education \\
\hline UFMG & Nature Conservancy Brazil \\
\hline Vitae Civilis & Federal University of Minas Gerais \\
\hline WB & Vitae Civilis Institute \\
\hline WWF-Brasil & World Bank \\
\hline & World Wildlife Fund Brazil \\
\hline
\end{tabular}

\begin{tabular}{|l|l} 
RESERCH & This research was carried out by CIFOR as part of the CGIAR Research Program on Forests, Trees and \\
PRoGRAM ON & Agroforestry (CRP-FTA). This collaborative program aims to enhance the management and use of forests, \\
Forests, Trees and & $\begin{array}{l}\text { agroforestry and tree genetic resources across the landscape from forests to farms. CIFOR leads CRP-FTA } \\
\text { in partnership with Bioversity International, CATIE, CIRAD, the International Center for Tropical Agriculture } \\
\text { and the World Agroforestry Centre. }\end{array}$
\end{tabular}

